\title{
Analysis and Forecasting of the Impact of Climatic Parameters on the Yield of Rain-Fed Rice Cultivation in the Office Riz Mopti in Mali
}

\author{
Angora Aman ${ }^{*}$, Moussa Nafogou', Hermann Vami N'Guessan $\mathrm{Bi}^{2}$, Yves K. Kouadio1, \\ Hélène Boyossoro Kouadio² \\ ${ }^{1}$ Tropical Climate Team, Laboratory of Atmospheric Physics and Fluid Mechanics (LAPA MF), \\ University of Felix Houphouet-Boigny, Abidjan, Cote d'Ivoire \\ ${ }^{2}$ University Center of Applied Research in Remote Sensing (CURAT), University of Felix Houphouet-Boigny, \\ Abidjan, Cote d'Ivoire \\ Email: *angora.aman@gmail.com
}

How to cite this paper: Aman, A., Nafogou, M., N'Guessan Bi, H.V., Kouadio, Y.K. and Kouadio, H.B. (2019) Analysis and Forecasting of the Impact of Climatic Parameters on the Yield of Rain-Fed Rice Cultivation in the Office Riz Mopti in Mali. Atmospheric and Climate Sciences, 9, 479-497. https://doi.org/10.4236/acs.2019.93032

Received: April 1, 2019

Accepted: July 22, 2019

Published: July 25, 2019

Copyright $\odot 2019$ by author(s) and Scientific Research Publishing Inc. This work is licensed under the Creative Commons Attribution International License (CC BY 4.0).

http://creativecommons.org/licenses/by/4.0/

\begin{abstract}
During the period spanning the 1970s and1980s, countries in the West African Sahel experienced severe drought. Its impact on agriculture and ecosystems has highlighted the importance of monitoring the Sahelian rainy season. In Sahelian countries such as Mali, rainfall is the major determinant of crop production. Unfortunately, rainfall is highly variable in time and space. Therefore, this study is conducted to analyze and forecast the impact of climatic parameters on the rain-fed rice yield cultivation in the Office Riz Mopti region. The data were collected from satellite imagery, archived meteorology data, yield and rice characteristics. The study employed Hanning filter to highlight interannual fluctuation, a test of Pettitt and the standardized precipitation index (SPI) to analyze the rainfall variability. Climate change scenarios under the RCP 8.5 scenario (HadGEM-2 ES) and agroclimatic (Cropwat) model are carried out to simulate the future climate and its impact on rice yields. The results of satellite image classifications of 1986 and 2016 show an increase of rice fields with a noticeable decrease of bare soil. The analysis of the SPI reveals that over the 30 years considered, $56.67 \%$ of the rainy seasons were dry (1986-2006) and $43.33 \%$ were wet (2007-2015). The modelling approach is applied over 1986-2006 and 2007-2015 periods-considered as typical dry and rainy years-and applied over the future, with forecasts of climate change scenarios in 2034. The results show a decrease in potential yield during dry and slightly wet years. The yields of rain-fed rice will be generally low between 2016 and 2027. Deficits are observed over the entire study area, in comparison with the potential yield. Thus, this situation could expose the population to food insecurity.
\end{abstract}




\section{Keywords}

Climate Change, Remote Sensing, Rain-Fed Rice, Forecast, Yield, Mali

\section{Introduction}

The rainfall in Sub-Saharan Africa is characterized by strong variability [1]. The drought recorded in the 1970s and 1980s has greatly affected the population as well as the economies and the ecosystems of the West Africa geographical area [2] [3] [4]. The drought observed in the Sahel during this period had no equivalent in the spatial dimension. Some of the striking illustrations of this drought are the southward displacement of isohyets by about $200 \mathrm{~km}$ over the whole region, and the dramatic shrinking of the area occupied by free waters in Lake Chad [5]. The recent study on interannual and intra-seasonal variability of precipitation in West Africa revealed that most Sub-Saharan countries are still experiencing phenomenal precipitation patterns [3].

The sector affected most is agriculture, through land degradation, decrease in productivity of crops, livestock and water resources [6]. The strong dependence on rain-fed agriculture implies exposure to climate variability in addition to the impact of the population growth on food security. It is clear that higher temperatures associated with greater variability in precipitation had caused malfunctions of agricultural seasons, disruption of the biological cycles of crops and damage to agricultural production. In the Sub-Saharan area, the regional distribution of crops follows the distribution of water, soils, and floodwater availability [7]. This water is obtained directly from rainfall, but the source of water is also climate-dependent.

Traditionally, rice has been the main staple food from the Gambia through western Cote d'Ivoire, and along the banks of the Niger River in Mali and Niger. In Mali particularly, millet, sorghum, peanuts and rice are traditionally the principal staple food. In 1973-74, rice policy in West Africa was at crossroads because of the unanticipated drought events. In effect, many projects have been implemented in order to increase agricultural production [7]. The specific objectives of the projects were to boost agricultural production in order to reduce food insecurity. The success of these projects was based on irrigation method to control flooding. This supposes that there would be enough water available. However, weather hazards are characterized by late and poor rainfall distribution over the period, and/or late/or early recession of floods has constituted the major obstacle to the success of agricultural projects implemented.

On the other hand, during the last two decades, many efforts were deployed to investigate the variability of the West African Monsoon (WAM) and its impacts in order to improve prediction of the impacts of its variability on West African agriculture [8] [9]. Its impacts have highlighted the importance of monitoring the Sahelian rainy season [8] [10]. A centre of excellence named AGRHYMET, 
which is a specialized institution of the Permanent Interstates Committee for Drought Control in the Sahel, was created in 1974 at the aftermaths of the severe droughts that affected the region in the early 1970s [5]. The main mission of this centre is to train experts in agrometeorology, hydrology, equipment maintenance on topics related to food security, climate change and sustainable natural resources management. Since 2012, considerable efforts are being made by AGRHYMET to forecast other characteristics of the rainy season-beginning and duration of the rainy season, and the potential duration of the dry spells during the critical growth stages of the major crops-that are relevant for rain-fed agriculture [5]. Generally, this prediction is available seasonally.

The variability and uncertainty of climatic conditions has drastic effect (low yield) on crop production, particularly on rice. This study, therefore, aims to analyze the rainfall variability and its impacts on rain-fed rice production in Office Riz Mopti region for the next ten years. The study of this variability and effect on the production will help for future planning to avert the effect of climatic change. A better understanding of present and future crop production will result from critical modelling with robust climate and agrometeorological models. The simulations in the Mopti region based on agrometeorological models enable the analysis of the response of crop to rising temperatures and rainfall variability. The first step of this study consists of an assessment of land use and land cover in this area during the last decades. Remote sensing technology could provide efficient methods for managing natural resources and monitoring environmental changes. Satellite imagery gives an effective platform to detect land use and land cover change over a period of time [11] [12].

This paper is therefore aimed at analyzing the climate variability with a focus on field meteorological dataset between 1986-2016 periods and forecasting the impact of the climatic parameters on the yield of rain-fed rice production on Mopti region. The projection of the rice production is obtained by using climate and agrometeorological models. So, the purpose of this paper could be summarized as follows: satellite imagery, field experimental meteorological data and the methodology for the future climate and crop simulations are described in Section 2. The results and discussions are presented in Section 3.

\section{Data and Methodology}

\subsection{Site Area}

Mopti region (Figure 1) is located in the centre of Mali between $5^{\circ} 30 \mathrm{~W}-6^{\circ} 45 \mathrm{~W}$ $13^{\circ} 45-15^{\circ} 45$. Geographically, the study region covers an area of about 79,017 $\mathrm{km}^{2}$ that represents $6.34 \%$ of Mali's total land area and includes the study zone of Office Riz Mopti $\left(3.53^{\circ} \mathrm{W}-4.69^{\circ} \mathrm{W} ; 14^{\circ} \mathrm{N}-15.51^{\circ} \mathrm{N}\right)$ which has an area of $7515 \mathrm{~km}^{2}$. Agriculture and breeding are the main economic activities of the 128,774 inhabitants and also includes 2018 villages [13]. The Mopti region is confined within the Sudano-Sahelian zone, which is predominantly characterized by climatic conditions of semi-arid to arid regimes at the north and a sub-humid 


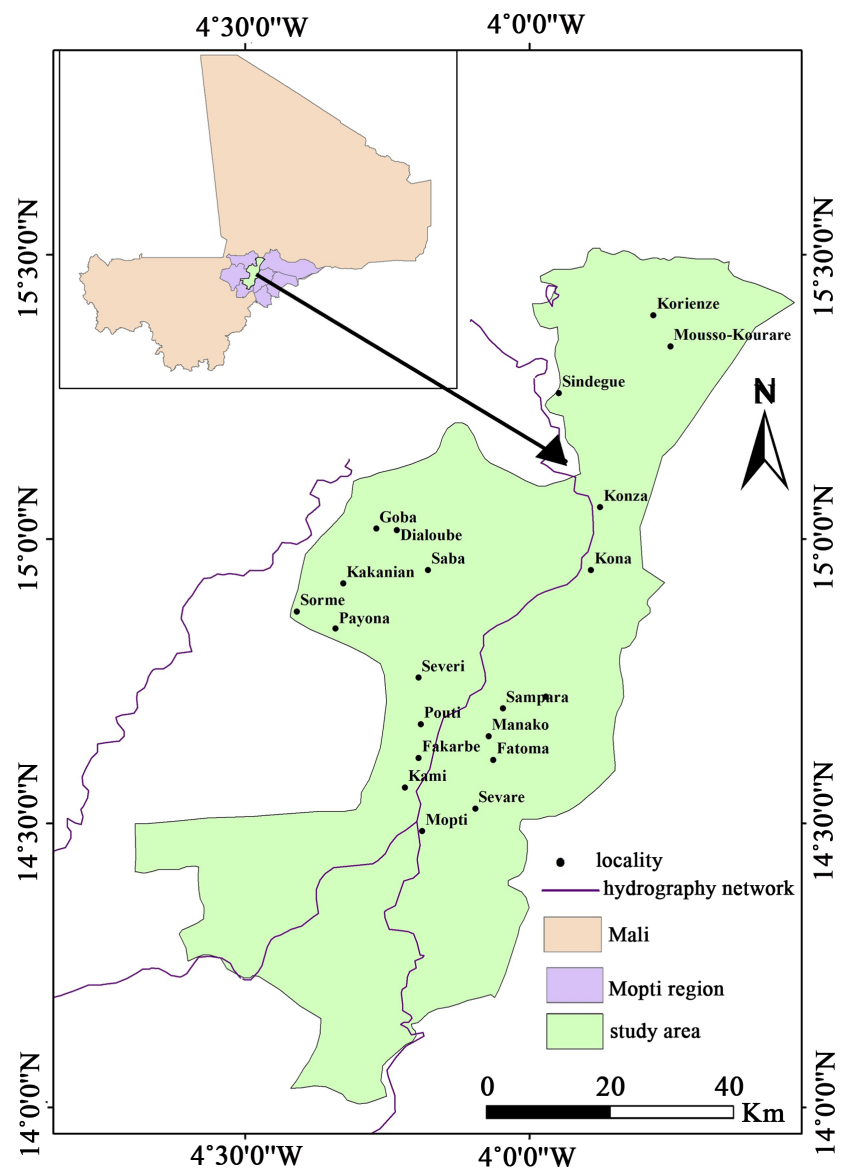

Figure 1. Location of the Mopti region.

zone at the south. The annual rainfall amount falls between $0-169 \mathrm{~mm}$ in December and August respectively, while the mean annual temperature is $29.38^{\circ} \mathrm{C}$. The years 1987 (with $30.42^{\circ} \mathrm{C}$ ) and 2014 (with $28.65^{\circ} \mathrm{C}$ ) were the warmest and the coldest respectively during which Mopti experienced drought in 1987 and flood in 2014 [14] [15] [16]. The mean interannual value of the relative humidity is $42 \%$, whereas the highest relative humidity ( $71.91 \%)$ is reached in August which represents the maximum of the seasonal cycle of the rainfall. The weakest humidity $(\sim 20.55 \%)$ is recorded particularly in March during the dry season from October-June.

In Mali, the principal types of soil can be divided into the following 5 main categories [17]: 1) slight ferralitic soils, 2) tropical ferruginous soils, 3) subarid soils, 4) hydromorphic soils and 5) vertisol soils.

The various soils found in Mali generally have several important constraints which limit the cultivable potential: low levels of fertility, deficiencies in phosphorus, potassium and sulphur and the strong sensitivity to wind and water erosion.

Nearly all the rice in Mali is grown on the hydromorphic soils of the Niger and Bani river basins, which support human and animal populations in the country. 


\subsection{Sources of Data}

The data used in this study are from satellite imagery and archived meteorology data, rice productivity, yield, rice varieties and rice phenology.

\section{Satellite Images}

This study is undertaken by using four digital images from the Landsat satellite (Table 1 ) over the Mopti region $\left(5^{\circ} 30 \mathrm{~W}-6^{\circ} 45 \mathrm{~W} ; 13^{\circ} 45-15^{\circ} 45\right)$. Two satellite images for the Landsat TM recorded in 1986 and two Landsat OLI acquired in 2016 are extracted freely from the USGS website https://earthexplorer.usgs.gov/. The 30-years difference between these two versions allows the changes in the region during this period to be interpreted.

The initial step is the pre-processing of Landsat images (scenes 197-50 and 197-49). It is summarized in a set of operations that increase the readability of the images and facilitate their interpretation. Then, the vegetation index (NDVI) is used to improve the perception of geographical objects by increasing the contrast and reducing the other themes.

Supervised classification from the coloured composition of the images is carried out using Maximum likelihood algorithm in ENVI 5.1. The supervised classification technique is preferred because the data of the study area is available and we have a prior knowledge of the area which will aid the classification. The images are then filtered through the convolution filter of Lee to improve the classification. This step is followed by the analysis of the land use, land cover change and the realization of the detection change matrix which results from the comparison between the pixels of the classification for two different dates [18].

Change detection statistics is computed in percentage to assess the change in land use and land cover from 1986 to 2016 according to Equation (1). This provides a percentage difference in images, thus quantifying the resultant change. Post classification confusion matrices were generated to obtain an accurate assessment.

$$
T c=\left[\left(\frac{S_{2}}{S_{1}}\right)^{\frac{1}{t}}-1\right] \times 100
$$

where:

$T c=$ mean annual rate of spatial expanding (\%).

$S_{1}$ and $S_{2}$ represent the surface area at the date $t_{1}$ and $t_{2}$ respectively $\left(t=t_{2}-\right.$ $\left.t_{1}>0\right)$.

The global rate change $T g$ is computed as follow:

Table 1. Characteristics of images acquisition.

\begin{tabular}{ccc}
\hline Image & (Path/Row) & Date \\
\hline Landsat TM & $197-49$ et $197-50$ & 25 October 1986 \\
Landsat OLI & $197-49$ et 197-50 & 23 November 2016 \\
\hline
\end{tabular}




$$
T g=\frac{S_{2}-S_{1}}{S_{1}} \times 100
$$

$T g$ is commonly used in land change studies [19].

\subsection{Meteorological Data}

Monthly rainfall, minimum and maximum temperature, relative humidity, insolation, mean wind speed and potential evapotranspiration data spanning the period of 1986-2015 were obtained from the Direction de l'Agence de la Météorologie du Mali (DAMM).

\subsection{Other in Situ Dataset}

Other type of data that are relevant to the characteristics of the rice phenology and varieties are also obtained from various sources $\left(\mathrm{BH}_{2}, \mathrm{DM}-16\right.$, GAMBIAKA KOKOUM, KHAO-GAEW (92-5-23), SHWETASSOKE, WAS 197-B-6-3-1). They were recorded by the Centre Régional de Recherche Agronomique de Mopti (CRRA/IER-Mopti). The data of sown areas, the productions and the yields of the rain-fed rice during 2002-2015 have been provided by the Direction Régionale de l'Office Riz Mopti. All these data aforementioned were used in calculating the water required for crop productivity in the Soudano-Sahelian zone. Lower water use indicates a decrease in crop yield.

\subsection{Future Climate and Crop Simulations}

The rainfall variability is analyzed by using Hanning filter to highlight interannual fluctuations and the standardized precipitation index (SPI) that describes both short-term and long-term impacts of drought for different time scales [20] [21].

In climate change study, there is always a question of whether the probability distribution remains constant or changes. Among the existing tests, the Pettitt test is one of the widely used tests in sensitivity correlation and linear trends [22]. The non-parametric test of Pettitt is carried out to study the stationarity of the time series and to determine the significant break in the series. This test allows the detection of a single shift at an unknown time $t$ [23].

The impact of the climate change on the cultural yields is also calculated by using HadGEM-2 ES data from the scenario RCP8.5 (see https://link.springer.com/content/pdf/10.1007\%2Fs10584-011-0149-y.pdf) in the year 2034. The HadGEM2-ES model of UK Met Office, which data simulations were obtained from British Atmospheric Data Center, has horizontal resolution of $1.875^{\circ} \times 1.2^{\circ}$ in the atmosphere, equivalent to about $140 \mathrm{~km}$ at middle latitudes, and $1^{\circ} \times 1^{\circ}$ in the ocean, with varying latitudinal resolution, which increases smoothly from $30^{\circ} \mathrm{N} / \mathrm{S}$ at $0.33^{\circ}$ at the equator. The precipitation and temperature patterns and expected future change (2073-2098) in Africa has been successfully investigated using HadGEM2-ES under CMIPS5 protocols for historical and future emission scenarios simulations [24]. This last model has been 
also used in the fifth intergovernmental panel for climate change (IPCC) report and in the coupled model intercomparison project phase 5 (CMIP5) [25].

The cultural yields are simulated through the CropWat 8.0 model for 1987 and 2005, herein used as dry and wet years respectively. This model originally developed by FAO [26] based on climate-soil-plant system, is then ran to evaluate the crop yield over the 2015-2034 period. The input data included cover crop, meteorology and soil]. This approach supposes the continued use of the same variety and the same cultural practices. The climate, pedologic and cultural data are used as inputs in the CropWat 8.0 model to forecast the actual and future climatic influences on the rain-fed rice. CropWat 8.0 is based on the evaluation of the soil water balance budget of the cultures and performance indicators. It uses the Penman-Monteith formulae to calculate the evapotranspiration of reference [27] [28]. Then, the potential yield is performed for each culture following the climate conditions of the considered year and the pedologic context. The yield reduction (Ky) is obtained through the CropWat model. In this study, the Gambiaka Kokoum variety (production $\sim 5 \mathrm{t} / \mathrm{ha}$ ) is used.

\section{Results and Discussions}

\subsection{Multi-Temporal Images Classification of Land Cover and Land Use Based on Landsat TM and OLI Imagery}

Landsat TM and Landsat OLI images acquired respectively from the years 1986 and 2016 were used to quantify temporal changes from 1986 to 2016 by image classification techniques. Image classification is performed on these images independently. The desired outcome of the imagery classification is to identify the basic land uses in the Office Riz Mopti region and the land use change from 1986 to 2016. The images of 1986 and 2016 were classified into four distinct land use and land cover categories such as water, rice fields, settlements and bare soil (Figure 2).

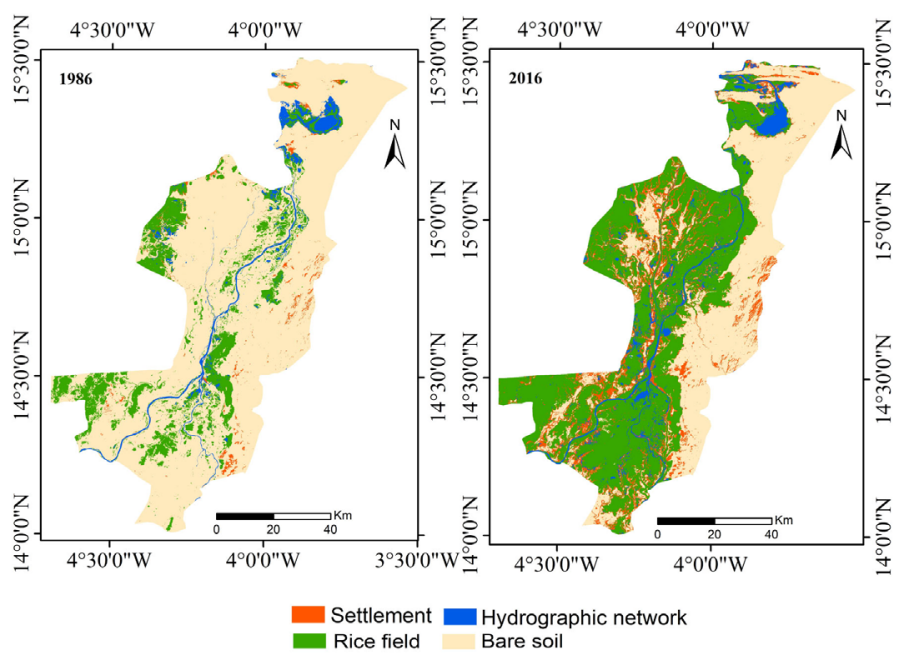

Figure 2. Thematic maps derived from Landsat images using a supervised classification (1986 and 2016). 
The accuracy of classified images was assessed using confusion matrices (Table 2 and Table 3). Most of the classified pixels associated with water, rice fields and settlements classes have a high percentage of overall accuracy. The overall accuracy of the classification in 1986 is $90.39 \%$ followed by $99 \%$ in 2016 . The classification results suggest high accuracy of remotely sensed data and reference data, where $80 \%$ accuracy results indicate strong agreement of Kappa values [29]. Vintrou [12] found crop accuracy between $66 \%$ and $75 \%$ when using MODIS imagery classification in Mali. The largest source of error in all the images is the confusion settlements and bare soils. The accuracies are around $43 \%$ and 33\% respectively in 1986 and 2016. One challenge in classifying land use and land cover in semi-arid region is the difficulty of accuracy in isolating the radiometric reflectance caused by vegetated cover from that caused by soil since the vegetation in such areas is typically sparse [30]. Knick et al. [30] noted also that sparse vegetation classes derived from satellite data contribute little to total radiation reflectance by satellite sensors in semi-arid regions. Bertelsen et al. [31] have compared 4 classification methods on Landsat 7 (ETM+) of Madiama (Mali) and concluded that using maximum likelihood and minimum distance achieved the best classification in this area.

Table 2. Confusion matrix derived from image classification of 1986.

\begin{tabular}{cccccccc}
\hline \multirow{2}{*}{$\begin{array}{c}\text { Classified } \\
\text { image }\end{array}$} & Water & Rice fields & Settlement & Bare soil & Total & Accuracy & Omission \\
\cline { 2 - 7 } Water & 93.65 & 2.86 & 4.65 & 0.46 & 4.49 & 78.51 & 21.49 \\
Rice field & 5.79 & 90.39 & 0.25 & 0.12 & 16.96 & 98.13 & 1.87 \\
Settlement & 0.21 & 0.95 & 43.59 & 6.31 & 5.84 & 14.88 & 85.12 \\
Bare soil & 0.34 & 5.80 & 51.52 & 93.11 & 72.72 & 97.10 & 2.90 \\
Total & 100.00 & 100.00 & 100.00 & 100.00 & 100.00 & & \\
Accuracy & 93.65 & 90.39 & 43.59 & 93.11 & & & \\
Omission & 6.35 & 9.61 & 56.41 & 6.89 & & & \\
\hline
\end{tabular}

Table 3. Confusion matrix derived from image classification of 2016.

\begin{tabular}{cccccccc}
\hline \multirow{2}{*}{$\begin{array}{c}\text { Classified } \\
\text { image }\end{array}$} & Water & Rice fields & Settlement & Bare soil & Total & Accuracy & Omission \\
\cline { 2 - 7 } Water & 91.89 & 0.76 & 0.93 & 0.00 & 3.96 & 90.61 & 9.39 \\
Rice field & 5.88 & 99.00 & 11.65 & 0.02 & 38.60 & 96.67 & 3.33 \\
Settlement & 0.71 & 0.02 & 33.21 & 0.20 & 3.12 & 95.69 & 4.31 \\
Bare soil & 1.52 & 0.22 & 54.21 & 99.78 & 54.33 & 90.77 & 9.23 \\
Total & 100.0 & 100.00 & 100.00 & 100.00 & 100.00 & & \\
Accuracy & 91.89 & 99.00 & 33.21 & 99.78 & & & \\
Omission & 8.11 & 1.00 & 66.79 & 0.22 & & \\
\hline
\end{tabular}


In 1986, the areas covered by water, rice fields, settlements, and bare soil were $3.8 \%, 14.8 \%, 1.5 \%$ and $79.9 \%$ (Figure 3 ) respectively. The bare soil surface decreases from $79.9 \%$ to $40.9 \%$ when the rice field areas increase from $14.8 \%$ to $48.3 \%$ from 1986 to 2016 . The Transition Matrix (Table 4) reveals that $40.8 \%$ of water surface has been transformed into rice fields during the 1986-2016 periods. The second important change is relative to the bare soil: $39.9 \%$ of bare soil areas were converted into rice fields. $32 \%$ of settlement was abandoned to rice fields. An increase in rice fields is noticed from 1986 to 2016 along with a noticeable decrease in bare soil. Table 4 indicates that it is likely the bare soils and water surfaces were converted to cropland. In reference to Table 5, many efforts were deployed to extend the rice cultivated fields between 1986 and 2016. This table shows that the global rate change Tg is very high for the settlement between 1986 and 2016 (around 246\%). According to [24], one of the consequences of the drought is the rapid deforestation of the sahelian zone resulting from the resettlement of nomadic people after losing their cattle. This had led to an increase in the human activity, such as increase the area devoted to crops in the Sahel since 1970, inducing an expansion of agriculture into areas poorly suited for crops [6]. The rice yield reported by [7] in the Mopti region from 1961 to 1976 was generally lower than $1.5 \mathrm{t} /$ ha (Table 6 ). The spatial extent of rice fields results also from the land degradation that occurred in the north between Gao and Mopti. According to [31], the major causes of land degradation stems from climatic conditions, include an arid environment and low and irregular rainfall patterns (climatic processes such as wind and water erosion). The aridity is becoming pronounced due to a reduction in the mean annual rainfall.

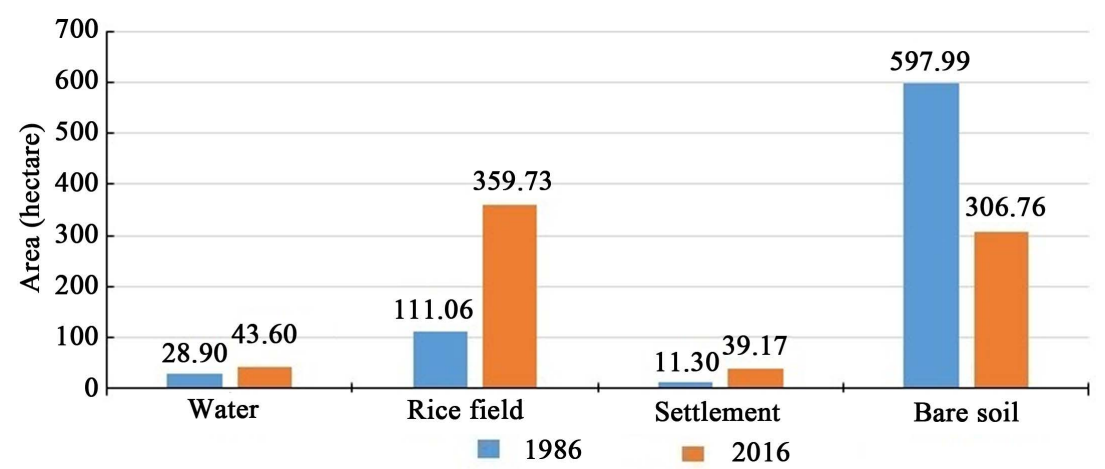

Figure 3. Land cover/land use coverage (ha) in 1986 and 2016 derived from the image classifications.

Table 4. Transition matrix computed from images classification of 1986 and 2016.

\begin{tabular}{ccccc}
\hline \multicolumn{5}{c}{ Image classification (1986) } \\
\hline Image classification (2016) & Water & Rice fields & Settlement & Bare soil \\
\hline Water & 58.858 & 4.459 & 4.668 & 3.53 \\
Rice fields & 40.804 & 94.963 & 32.199 & 39.938 \\
Settlement & 0.154 & 0.192 & 7.724 & 6.361 \\
Bare soil & 0.185 & 0.386 & 55.409 & 50.171 \\
\hline
\end{tabular}


Table 5. Mean annual rate change and global rate change during 1986-2016 periods.

\begin{tabular}{ccc}
\hline Informational Classes & $\mathrm{Tc}(\%)$ & $\mathrm{Tg}(\%)$ \\
\hline Water & 1.33 & 50.87 \\
Rice field & 3.86 & 223.887 \\
Settlement & 4.09 & 246.687 \\
Bare soil & -2.13 & -48.702 \\
\hline
\end{tabular}

Table 6. Rice yield reported by [7] at Mopti region.

\begin{tabular}{|c|c|}
\hline Year & Rice Yields (mt/ha) \\
\hline 1961 & 1.088 \\
\hline 1962 & 1.016 \\
\hline 1963 & 0.950 \\
\hline 1964 & 1.341 \\
\hline 1965 & 0.997 \\
\hline 1966 & 0.959 \\
\hline 1967 & 0.890 \\
\hline 1968 & 0.857 \\
\hline 1969 & 0.836 \\
\hline 1970 & 1.174 \\
\hline 1971 & 0.977 \\
\hline 1972 & 1.348 \\
\hline 1973 & 0.527 \\
\hline 1974 & 0.724 \\
\hline 1975 & 0.914 \\
\hline 1976 & 1.116 \\
\hline
\end{tabular}

\subsection{Rainfall Variability}

The analysis of the climatic periods is based on the Standardized Precipitation Index (SPI) usually carried out to quantify wetness/dryness of a given rainy season, with respect to the climatology [21]. This index is often used in a very simplistic way by assessing that the rainy season is wet if the SPI $>0$ and dry if the SPI $<0[21]$.

The SPI carried out during the 1986-2016 period reveals that over the 30 years considered, $56.67 \%$ of the rainy seasons were dry and $43.33 \%$ were wet (Figure 4). Figure 5 shows the variation of the SPI from 1986 to 2016. Two periods are clearly identified: 1986-2006 was dry and 2007-2015 corresponds to a wet period. The annual mean rainfall recorded during $1986-2015$ is equal to $439.7 \mathrm{~mm}$ during the rainy season. Olivry et al. [32] reported a rainfall mean value of $415 \mathrm{~mm}$ at Mopti. The annual rainfall at the six regional capitals during a 30 -year period (1950-1980) is in Table 7 [7]. During this period, the annual rainfall recorded at 


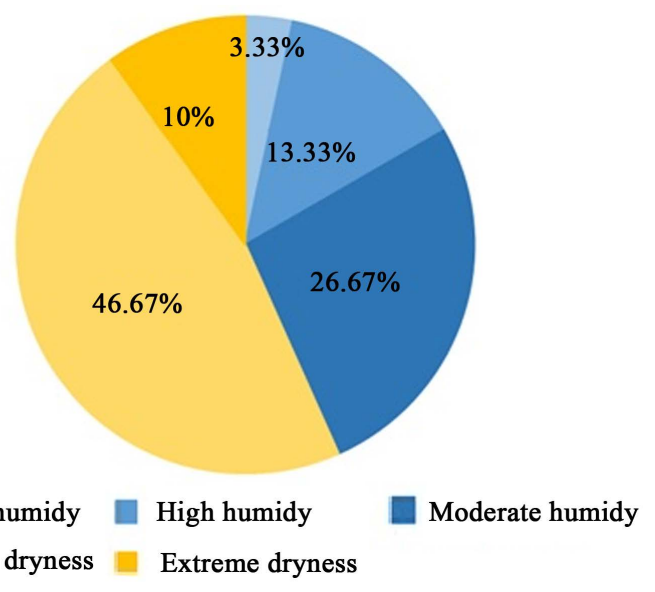

Figure 4. Distribution of the wet and dry seasons over 1986-2016.

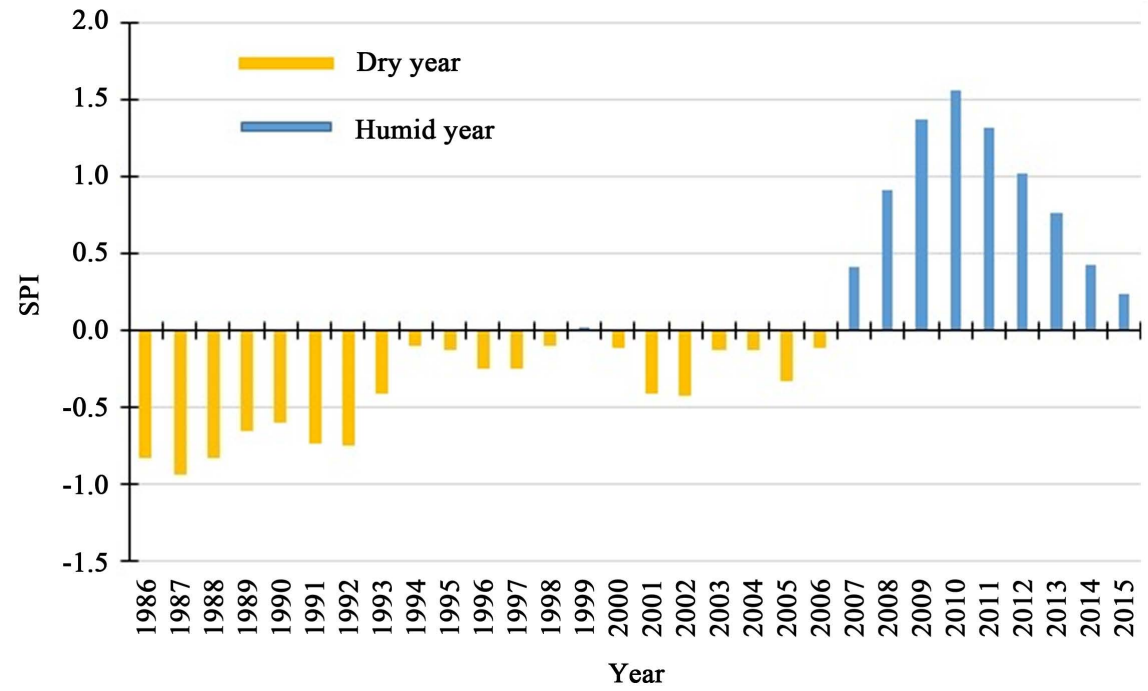

Figure 5. SPI computed from 1986 to 2016.

Table 7. Annual rainfall at the six regional capitals in Mali from 1950 to 1980 [7].

\begin{tabular}{cc}
\hline Site & Annual rainfall (mm) \\
Gao & 260 \\
Mopti & 520 \\
Kayes & 720 \\
Segou & 720 \\
Bamako & 1050 \\
Sikasso & 1300 \\
\hline
\end{tabular}

Mopti was $520 \mathrm{~mm}$ showing a decrease of $100 \mathrm{~mm}$ compared to those recorded during 1986-2015. In Figure 6, an alternation between wet and dry years from 1994 to 2006 is observed showing a new mode of variability. The trend reveals that 2006 represents a transition year. This result is in accordance with the 


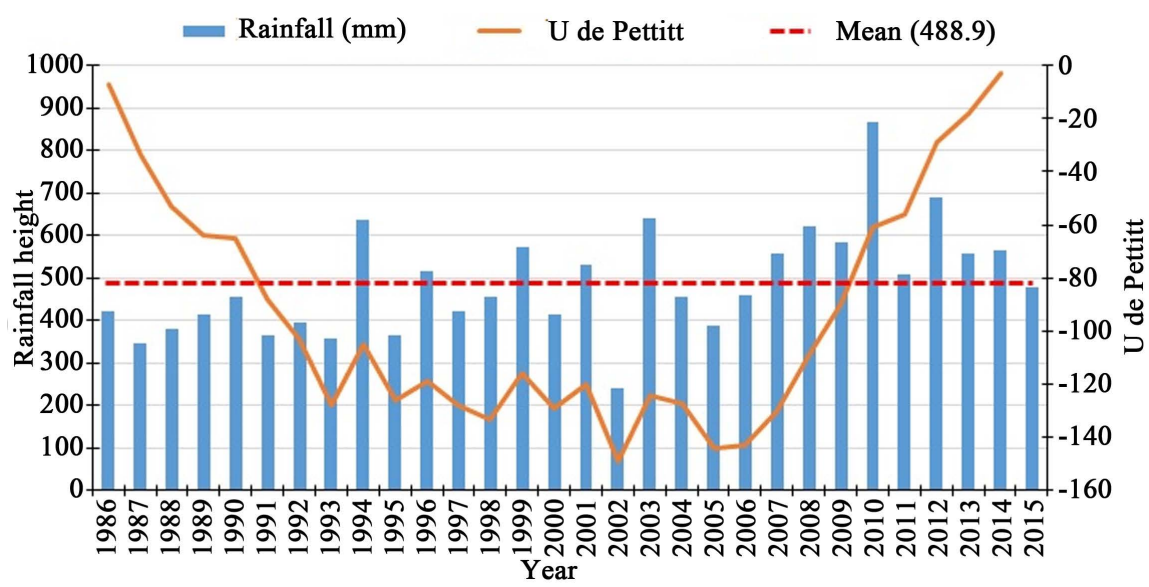

Figure 6. Detection of the significant break in the rainfall regime over the period 1986-2016 based on the Pettitt test.

analysis of Sahelian SPI calculated on the basis of data from 600 stations monitored by the AGRHYMET Regional Centre which mentions two distinct periods [5]: the first period from 1950-1969 was characterized by a persistence of wet years and the second period from 1970 to 1993, by a persistence of over twenty dry years. So, the 1970s marked a change in climate in the Sahel. This study based on the AGRHYMET stations shows three wet years recorded in the Sahel 1994-1999-2003.

A study conducted by [33] based on rainfall gauges data over 1950-2006 period reveals that the period 1970-1990 was characterized by a continuous rainfall deficit of $50 \%$ as compared to the previous $1950-1969$ period at $15^{\circ} \mathrm{N}$. They also noted a greater interannual variability during 1970-1990 and a contrast between the western Sahel which remained dry and the eastern Sahel including Mopti region returning to wetter conditions. This greater rainfall interannual variability was one of the major reasons for the African Monsoon Multidisciplinary Analysis (AMMA) program [9] [34]. This climate variability has a great impact on rain-fed agriculture and obviously on population. AMMA program was conducted in the West Africa region in order to better understand the West African Monsoon and its variability and to improve prediction of the impact of this variability in West Africa societies [9].

The last 8 years (2007-2015) are characterized by a positive Standard Precipitation Index demonstrating the wetness of the rainy seasons during this period. The annual mean rainfall height is $603 \mathrm{~mm}$. In this study, the non-parametric Pettitt change point test is then used to detect the occurrence of the abrupt change. This result is confirmed by the segmentation of Hubert and the Pettitt test. The variation of the $U$ variable of the Pettitt test shows clearly that 2006 can be considered as a shift in the 1986-2016 time series (Figure 6). According to the Pettitt test, a shift is observed in 2006. After 20 years of drought, the first wet years were recorded in 1994, 1999 and 2003 [5]. The continuous wet years are observed after 2006. Since then, the situation has improved. 


\subsection{Analysis of the Climatic Trend during the Next Twenty Years and Its Impact on Yield Rice Cultivation}

The main objective of this section is to determine the climatic trend for the next twenty years in the Office Riz Mopti region and predict the yield rice under this climatic condition. The climatic trend is provided by the global climatic model HadGEM-2 (see the website

https://portal.enes.org/models/earthsystem-models/metoffice-hadley-centre/hadgem 2-es). The agroclimatic model (CropWat) is then applied for crop monitoring and forecasting. Here, the outcome provided by this model at the local level impact assessment on rice production is based on climatic changes scenario HadGEM-2 ES.

The temperature and precipitation patterns are investigated by using both observational and modeling data. Table 8 and Table 9 give the mean interannual precipitations and temperature derived respectively from observations (1986-2015) and simulation data (2015-2034). The mean interannual rainfall computed from the climatic model is around $546 \mathrm{~mm}$ for the $2015-2034$ periods. In comparison to the actual value of mean interannual rainfall value which is $589 \mathrm{~mm}(1986-2006)$, the difference is marginal. The mean interannual temperature derived from observations during $1986-2015$ periods is $29.38^{\circ} \mathrm{C}$. The temperature estimated from HadGEM-2 ES model is $30.93^{\circ} \mathrm{C}$ for $2015-2034$, which implies a temperature increase of $1.55^{\circ} \mathrm{C}$. However, we must keep in mind that those results can be biased by errors resulting from the representation on ENSO events in the model. The ENSO events impact in West African countries close to the position of the ITCZ by drying these zones during the summer to early autumn as well as from winter to early spring [24].

The potential yield of the rice production in the Office Riz Mopti based on the optimal condition is $5 \mathrm{t} / \mathrm{ha}$. In order to evaluate the climatic variability on the yield, we have considered two climatic situations characterized by 1986-2006 (dry) and 2006-2015 (humid) periods. The agroclimatic model CropWat was run to simulate the yield of rice production when considering the two climatic conditions. The potential yield decrease is $77.9 \%$ and $37.7 \%$ respectively during the dry and wet conditions (Table 10). So, the yields computed under the dry climatic condition is $1.105 \mathrm{t} / \mathrm{ha}$ and $3.115 \mathrm{t} / \mathrm{ha}$ in a wet situation. The yield obtained under the dry climatic condition can be compared with that reported

Table 8. Mean interannual rainfall computed from observations and HadGEM-2 model.

\begin{tabular}{lcc}
\hline & $\begin{array}{c}\text { Mean interannual rainfall } \\
\text { (observation) 1986-2015 }\end{array}$ & $\begin{array}{c}\text { Mean interannual rainfall } \\
\text { (prediction) 2015-2034 }\end{array}$ \\
\hline Mean interannual $(\mathrm{mm})$ & 488.91 & 546.94 \\
\hline
\end{tabular}

Table 9. Mean interannual temperature derived from observations (1986-2015) and HadGEM-2 model (2015-2034).

\begin{tabular}{ccc}
\hline & $\begin{array}{c}\text { Mean interannual temperature } \\
\text { (observation) 1986-2015 }\end{array}$ & $\begin{array}{c}\text { Mean interannual temperature } \\
\text { (prediction) 2015-2034 }\end{array}$ \\
\hline Mean interannual $\left({ }^{\circ} \mathrm{C}\right)$ & 29.38 & 30.93
\end{tabular}


Table 10. Rice yield simulated for dry and wet years based on CropWat model.

\begin{tabular}{cccc}
\hline Year & Rdtpot (t/ha) & Ky $(\%)$ & Rdtpot_act (t/ha) \\
\hline Dry (1987) & 5 & 77.9 & 1.105 \\
Wet (2015) & 5 & 37.7 & 3.115 \\
\hline
\end{tabular}

by [7] in 1961-1976 (see Table 6). This table shows that the yields were low, between $0.527 \mathrm{t} / \mathrm{ha}$ to $1.341 \mathrm{t} / \mathrm{ha}$. Note that the minimum, which corresponds to $0.527 \mathrm{t} / \mathrm{ha}$, was recorded in 1973 during the severe drought experienced in Mali. These values reported in Table 6 are in accordance with that obtained under the dry climatic conditions simulations. The values reported in this table show the rice yields remained very low (lower than $1.5 \mathrm{t} / \mathrm{ha}$ ) even in the persistence of wet years (1950-1969). So, the role of the soils should not be ignored. Soils of the office du Niger are essentially acid with average $\mathrm{pH}$ below 6.5 , the optimum $\mathrm{pH}$ for rice and most vegetable crops [35]. The decline in rice yield observed is exacerbated by land degradation in this area. The natural fertility of soils is low; organic matter is lacking and soils are deficient in nitrogen, phosphorus and sulfur. This ecological belt is now the most degraded in Mali as a result of cultivation on marginal soils, salinization, overgrazing, water and wind erosion and the removal of crop residues [35]. Natural moisture infiltration is poor due to the combination of high rainfall intensity and low absorptive capacity of soils [36].

The outcomes of the climatic model HadGEM-2 provide the input parameters for the agroclimatic model CropWat for 2015-2034 periods. The prediction of the yield for the year 2027 is estimated at $0.855 \mathrm{t} / \mathrm{ha}$ based on CropWat model (Table 11). In comparison to those obtained during the dry and the wet climatic conditions, this value is low. Recent studies of the CILSS/AGRHYMET [6] have shown that yields of crops such as millet/sorghum will fall by over $10 \%$ when there is a $+2^{\circ} \mathrm{C}$ increase in temperature and insignificant rainfall variations in 2050. Simulations conducted across the globe [25] show a relatively large decline (from $20 \%$ to $50 \%$ ) of cereal crops throughout the Sahel, from Niger to Senegal in 2050. Since the '70s, the principal objective of Malian rice policy has been to achieve national food security [7]. We hope that AGRHYMET will contribute significantly to tackle challenges related to population growth and all climate hazards, including climate change impact assessment on agriculture and water resources, as well as adaptation studies [5]. Increased rice production with reliable methods of water control and soil management could be an important way to ameliorate the security food in Mali. The vast potential of rain-fed agriculture needs to be unlocked through knowledge that is based on the management of natural resources for increasing productivity and income to achieve food security. This work needs to be improved as it is unusual to integrate remote sensing imagery, in situ measurements and models in such studies. As pointed out by [37], very different sources of uncertainty are involved including scenario uncertainty, model uncertainty, and model internal variability. A critical issue in climatic change impact studies on rain-fed agriculture requires an estimation of the contribution of different uncertainties sources. 
Table 11. Rice yield reduction for the 2016-2027 periods.

\begin{tabular}{cccc}
\hline Year & Rdtpot (t/ha) & Ky (\%) & Rdtpot_act (t/ha) \\
\hline 2027 & 5 & 82.9 & 0.855 \\
\hline
\end{tabular}

\section{Conclusions}

The drought that occurred in the West African Sahel during 1970s-1980s was exceptional by its severity and its spatial extent. In Mali, food crops are mainly rain-fed and dominated by grains like rice, sorghum, and maize. The effects of the variability and uncertainty of climatic condition have exposed the population to severe water scarcity, leading to major food and health crisis. The present study is a contribution to the understanding of climate variability, and its impact on the yield of rain-fed rice in the Office Rice Mopti area in Mali. It consisted of quantifying the land use/land cover change over the years based on remotely sensed data, characterizing climate variability, analyzing its evolution by 2034 and evaluating its impact on rain-fed rice cultivation.

Results from 1986 and 2016 images classification showed a more consistent change. There is a significant increase of rice fields from 1986 to 2016. The increase in the area devoted to rice fields in the Mopti region is the consequence of the drought observed in the Sahel since 1970 and possibly due to land degradation in this area. The characterization of climate variability based on application of the Nicholson index method and the 2nd order Hanning low-pass filter method to the long-term rainfall series allowed the identification of dry (1986-2006) and wet (2007-2015) during the study. The rainfall and temperature predictions in the Office Riz Mopti zone derived from the HadGEM2-ES model reveal a positive trend of about $58 \mathrm{~mm}$ of rainfall over the 2015-2034 periods and a temperature increase of $1.5^{\circ} \mathrm{C}$ over the period 2015-2034. Modelling of the most popular crop yields in the Mopti Riz zone has covered both the historical period-targeting typical years (dry and wet)-and future projections (2027). Over the historical periods, there is a decrease in the potential yield of different crops during dry years and a slight decrease during wet years. The rice yield obtained under the dry climatic condition is low (around $1.105 \mathrm{t} / \mathrm{ha}$ ). This value is comparable to that reported in the 1960s. The predicted yield is estimated at $3.115 \mathrm{t} / \mathrm{ha}$ in 2027. The relatively low yield values could be primarily attributed to the climate conditions but it is also the consequence of land degradation in the Mopti area. Considering climate change scenarios, a fall in potential yields is generally predictable under the Rcp 8.5 scenario. This study is the first investigation carried out by integrating field data, models and satellite images into Mopti Rice Office area in Mali. It could provide a better understanding of the impact of climate change on rice production and could serve as a decision support tool for food security.

\section{Acknowledgements}

The authors thank the Direction de l'Agence de la Météorologie du Mali (DAMM), 
Direction Régionale Office Riz Mopti and Centre Régional de Recherche Agronomique de Mopti (CRRA/IER-Mopti) for freely providing data on the meteorology, characteristics of the land and the phenology of the rice varieties respectively.

The ENSEMBLES data used in this work was funded by the EU FP6 Integrated Project ENSEMBLES (Contract number 505539) whose support is gratefully acknowledged.

The authors wish to thank the reviewers for their constructive remarks.

\section{Conflicts of Interest}

The authors declare no conflicts of interest regarding the publication of this paper.

\section{References}

[1] Nicholson, S.E. (1993) An Overview of African's Rainfall Fluctuation of the Last Decade. International Journal of Climatology, 6, 1463-1466. https://doi.org/10.1175/1520-0442(1993)006<1463:AOOARF $>2.0 . C O ; 2$

[2] Hulme, M. (1996) Recent Climatic Change in the World's Drylands. Geophysic Research Letters, 23, 61-94. https://doi.org/10.1029/95GL03586

[3] Nicholson, S.E. (2001) Climatic and Environmental Change in Africa during the Last Two Centuries. Climate Research, 17, 123-144. https://www.int-res.com/articles/cr2001/17/c017p123.pdf https://doi.org/10.3354/cr017123

[4] Le Barbé, L., Lebel, T. and Tapsoba, D. (2002) Rainfall Variability in West Africa during the Years 1950-1990. Journal of Climate, 15, 187-202. https://journals.ametsoc.org/doi/full/10.1175/1520-0442\%282002\%29015\%3C0187 \%3ARVIWAD\%3E2.0.CO\%3B2 https://doi.org/10.1175/1520-0442(2002)015<0187:RVIWAD>2.0.CO;2

[5] Traore, S.B., Ali, A., Tinni, S.H., Samake, M., Garba, I., Maigari, I., Alhassane, A., Samba, A., Diao, M.B., Atta, S., Dieye, P.O., Nacro, H.B. and Bouafou, K.G.M. (2014) AGRHYMET: A Drought Monitoring and Capacity Building Center in the West Africa. Weather and Climate Extremes, 3, 22-30. https://doi.org/10.1016/j.wace.2014.03.008

[6] Salack, S. and Sarr, B. (2006) Evaluation de l'incidence des changements climatiques sur la culture du riz pluvial et irrigué dans les pays du CILSS. Rapport de stage au Centre AGRHYMET, Département Formation et Recherche, 29 p. https://www.academia.edu/294240/Salack_S._Sarr_B._\%C3\%89valuation_de_1_inci dence_des_changements_climatiques_sur_la_culture_du_riz_pluvial_et_irrigu\%C3 \%A9_dans_les_pays_du_CILSS_2006

[7] Pearson, S.R., Stryker, J.D. and Humphreys, C.P. (1981) Rice in West Africa-Policy and Economics. Standard University Press, Stanford, 486 p. https://www.cabdirect.org/cabdirect/abstract/19836747230

[8] Ali, A., Lebel, T. and Amani, A. (2005) Estimation of Rainfall in the Sahel. Part 1: Error Function. Journal of Applied Meteorology, 44, 1691-1706. https://doi.org/10.1175/JAM2304.1

[9] Lebel, T., Cappelaere, B., Hanan, N., Levis, S., Descroix, L., Galle, S., Kergoat, L., Mougin, E., Peugeot, C., Séguis, L. and Vieux, B. (2009) AMMA-CATCH Studies in 
the Sahelian Region of West Africa: An Overview. Journal of Hydrology, 375, 3-13. https://doi.org/10.1016/j.jhydrol.2009.03.020

[10] Nicholson, S.E., Some, B. and Kone, B. (2000) A Note on Recent Rainfall Conditions in West Africa, Including the Rainy Season of the 1997 el Niño Year. Journal of Climate, 13, 2628-2640. https://doi.org/10.1175/1520-0442(2000)013<2628:AAORRC>2.0.CO;2

[11] Reis, S. (2008) Analyzing Land Use/Land Cover Changes Using Remote Sensing and GIS in Rize, North-East Turkey. Sensors, 8, 6188-6202. https://doi.org/10.3390/s8106188

[12] Vintrou, E., Desbrosse, A., Bégué, A., Traoré, S., Baron, C. and Lo Seen, D. (2012) Crop Area Mapping in West Africa Using Landscape Stratification of MODIS Time Series and Comparison with Existing Global Land Products. International Journal of Applied Earth Observation and Geoinformation, 14, 83-93. https://doi.org/10.1016/j.jag.2011.06.010

[13] Ministère du développement rural (2014) Annuaire statistique 2013 secteur du développement rural. 80 p. https://searchworks.stanford.edu/view/8653985

[14] (1987) Annuaire statistique du Mali. 218 p. https://www.malikunnafoni.com/bibliostat/docs/030108028_dnsi_1989.pdf

[15] (2013) Annuaire statistique du Mali-Secteur dévelopement rural. 80 p. http://mali.countrystat.org/fileadmin/user_upload/countrystat_fenix/congo/docs/A nnuaire\%202014.pdf

[16] Aich, V., Koné, B., Hattermann, F.F. and Muller, E.N. (2014) Floods in the Niger Basin-Analysis and Attribution. Natural Hazards Earth System Sciences Discussion, 2, 5171-5212. https://doi.org/10.5194/nhessd-2-5171-2014

[17] World Bank (2012) Mali: Options for Preparing a Sustainable Land Management (SLM) Program in Mali Consistent with TerrAfrica for World Bank Engagement at the Country Level. World Bank, Washington DC.

http://documents.worldbank.org/curated/en/101971468282246575/Mali-Options-fo r-preparing-a-sustainable-land-management-SLM-program-in-Mali-consistent-wit h-TerrAfrica-for-World-Bank-engagement-at-the-country-level

[18] Girard, M.-C. and Girard, C.M. (2010) Traitement des données de télédetection-Environnement et Ressources naturelles. 2ème Edition, Parution, Dunod, 553 p.

https://www.eyrolles.com/Sciences/Livre/traitement-des-donnees-de-teledetection$\underline{9782100548507}$

[19] Hadjadj, M.F. (2011) Apport des SIG et des images satellites pour la cartographie numérique de la forêt du Chettabah (Wilaya de constantine): Modélisation climatique et classification. Mémoire de fin d'études, Université El-Hadj Lakhdar Batna, Constantine, 178 p. http://www.secheresse.info/spip.php?article14388

[20] McKee, T.B., Doeskenet, N.J. and Kleist, J. (1993) The Relationship of Drought Frequency and Duration to Time Scale. 8th Conference on Applied Climatology, Anaheim, 17-22 January 1993, 179-184.

[21] Ali, A. and Lebel, T. (2009) The Sahelian Standardized Rainfall Index Revisited. International Journal of Climatology, 29, 1705-1714. https://doi.org/10.1002/joc.1832

[22] Pettitt, A.N. (1979) A Non-Parametric Approach to the Change-Point Problem. Journal of the Royal Society: Series C (Applied Statistics), 28, 126-135. https://doi.org/10.2307/2346729

[23] Hubert, P., Servat, E., Paturel, J.-E., Kouamé, B., Bendjoudi, H., Carbonnel, J.-P. and 
Lubès-Niel, H. (1998) La procédure de segmentation, dix ans après. In: Proceedings of the Abidjan Conference on the Water Resources Variability in Africa during the 20 th Century, IAHS Publ., No. 252, 267-273.

[24] Dike, V.N., Shimizu, M.H., Diallo, M., Lin, Z., Nwofor, O.K. and Chineke, T.C. (2015) Modelling Present and Future African Climate Using CMIP5 Scenarios in HadGEM2-ES. International Journal of Climatology, 35, 1784-1799. https://doi.org/10.1002/joc.4084

[25] Betts, R.A., Golding, N., Gonzalez, N., Gornall, J., Kahana, R., Kay, G., Mitchell, L. and Wiltshire, A. (2015) Climate and Land Use Impacts on Global Terrestrial Ecosystems and River Flows in the HadGEM2-ES Earth System Model Using Representative Concentration Pathways. Biogeosciences, 12, 1317-1338. https://doi.org/10.5194/bg-12-1317-2015

[26] FAO (2008) Conférence de haut niveau sur la sécurité alimentaire mondiale. Les défis du changement climatique et des bioénergies. Rome, Italie HLC/08/INF/5.

[27] Kuo, S.F., Lin, B.J. and Shieh, H.J. (2001) CropWat Model to Evaluate Crop Water in Taiwan. International Commission in Irrigation and Drainage, 1 st Asian Region Conference, 16-21 September 2001, Seoul, 15 p. https://www.researchgate.net/publication/265197839_CROPWAT_MODEL_TO_E VALUATE_CROP_WATER_REQUIREMENTS_IN_TAIWAN

[28] Etissa, E., Dechassa, N. and Allemayehu, Y. (2016) Estimation of Yield Response (Ky) and Validation of CropWat for Tomato under Different Irrigation Regimes. Irrigation \& Drainage Systems Engineering, 5, 1-6. https://doi.org/10.4172/2168-9768.1000167

[29] Congalton, R.G. and Green, K. (2009) Assessing of Remotely Sensed Data: Principal and Practices. 2nd Edition, Lewis Publishers, Boca Raton. https://doi.org/10.1201/9781420055139

[30] Knick, S.T., Zariello, T.J. and Rotenberry, J.T. (1997) Supervised Classification of Landsat Thematic Mapper Imagery in a Semi-Arid Rangeland by Nonparametric Discriminant Analysis. Photogrammetric Engineering and remote sensing, 63, 79-86.

https://www.asprs.org/wp-content/uploads/pers/1997journal/jan/1997_jan_79-86.p df

[31] Bertelsen, M., Heatwole, C., Moore, K. and Badini, O. (2001) Multi-Temporal Classification Land Cover Using Landsat 7 Imagery in Madiama, Mali. SANREM CRSP Research Scientific Synthesis Conference, Athens, 28-30 November 2001, Paper No. 200000.

https://vtechworks.lib.vt.edu/bitstream/handle/10919/65276/192_Bertelsen.pdf?seq $\underline{\text { uence }=1}$

[32] Olivry, J.C., Bricquet, J.P., Bamba, F. and Diarra, M. (1995) Le régime hydrologique du Niger supérieur et le déficit des 2 dernières décennies. In: Olivry, J.C. and Boulègue, J., Eds., Grands Bassins Fluviaux, Actes du Colloque PEGI, Colloques et Séminaires ORSTOM, 251-266.

[33] Lebel, T. and Ali, A. (2009) Recent Trends in the Central and Western Sahel Rainfall Regime (1990-2007). Journal of Hydrology, 375, 52-64.

https://doi.org/10.1016/j.jhydrol.2008.11.030

[34] Redelsperger, J.-L, Tomcroft, C.D., Diedhiou, A., Lebel, T., Parker, D.J. and Polcher, J. (2006) African Monsoon Multidisciplinary Analysis: An International Research Project and Field Campaign. American Meteorology Society, Boston, 1739-1746. https://journals.ametsoc.org/doi/pdf/10.1175/BAMS-87-12-1739 https://doi.org/10.1175/BAMS-87-12-1739 
[35] Ballo, A. (2006) Dégradation par alcanisation des sols en zone Office du Niger. Mémoire DEA, Université de Bamako. ISFRA, 37.

[36] Day, J.C. and Aillery, M.P. (1988) Soil Moisture Management in Mali: A Case Study Analysis for West Africa. Agricultural Economics, 2, 209-222.

https://doi.org/10.1016/0169-5150(88)90003-5

[37] Dobler, C., Hagemann, S., Wilby, R.L. and Sötter, J. (2012) Quantifying Sources of Uncertainty in Hydrological Projections in an Alpine Watershed. Hydrology and Earth System Sciences, 16, 4343-4360. https://doi.org/10.5194/hess-16-4343-2012 